\title{
Penguatan Capacity Building pada Kelompok Perawatan Diri (KPD) Kusta Sumber Waras melalui Kegiatan Pemanfaatan Kompos dan Mikroorganisme Lokal (MOL) di Puskesmas Kecamatan Slahung Kabupaten Ponorogo
}

\author{
Alfu Laila ${ }^{1}$, Use Etica ${ }^{1}$, Lutfy Ditya Cahyanti ${ }^{{ }^{*}}$ \\ Fakultas Sains dan Teknologi, Universitas Darussalam Gontor \\ lutfyditya@unida.gontor.ac.id
}

\begin{abstract}
Partners in this people empowerment program was KPD Leprosy Sumber Waras. Self Care Group (KPD) Sumber W aras is a group of leprosy patients or who have recovered from leprosy, which was initiated by Centre Public Healthy at Slahung District, Ponorogo city, East Java. The problems faced by partners were social and economic problems. The purpose of these people empowerment program was after this program the members of KPD skillfully to making compost and MOL (local microorganisms) independently. Futhermore, would improve the economy side of leprosy KPD members. Stages of activities undertaken in this program included preimplementation stage that were 1) Socialization 2) Preparation tools and materials. The second stage was the implementation stage including: 1) Composting material 2) Material and practice of making the MOL. From this program, it could be concluded that 1) Partners have understood the material of composting and MOL 2) Partners have been able to make MOL 3) These people empowerment activities have been able to overcome the problems of partners.
\end{abstract}

Keywords: Leprosy, Composting, MOL, People Empowerment

\section{Pendahuluan}

Kelompok Perawatan Diri (KPD) Sumber Waras merupakan kelompok penderita kusta ataupun yang telah sembuh dari kusta, yang dibentuk dan digagas oleh Puskesmas Kecamatan Slahung. Kusta ialah penyakit menular sehingga penderita kusta atau bahkan yang sudah sembuh mengalami permasalahan yang kompleks. Permasalahan tersebut tidak hanya masalah kesehatan akan tetapi meluas pada masalah ekonomi dan sosial. Salah satu fungsi didirikannya KPD ini ialah untuk mempercepat kesembuhan penderita kusta. Adanya KPD akan meningkatkan interaksi sesama penderita kusta dan bisa mempercepat proses penyembuhannya. Proses kesembuhan dari penyakit kusta akan berjalan lebih cepat karena sesama anggota akan saling mendukung, saling menghibur dan saling mengingatkan tentang pengobatan. Kegiatan KPD kusta yang rutin dilaksanakan 35 hari sekali, sebelum adanya kegiatan IbM (Iptek Bagi Masyarakat), pertemuan rutin diisi dengan penyuluhan kesehatan, kegiatan arisan, dan juga pelatihan-pelatihan yang akan 
membantu meningkatkan tingkat kepercayaan diri para angggota KPD Kusta. Partisipasi penderita kusta dalam kegiatan Kelompok Perawatan Diri (KPD) di Puskesmas Kec. Slahung meliputi keikutsertaan penderita kusta dalam memecahkan masalah kesehatan mereka sendiri. Di KPD Kusta ini, penderita kusta sendirilah yang aktif memikirkan, merencanakan, melaksanakan, dan mengevaluasi program-program dalam kegiatan KPD.

Permasalahan yang dialami oleh anggota KPD kusta Puskesmas Kecamatan Slahung adalah masalah sosial dan ekonomi. Hal ini disebabkan anggota KPD Kusta seringkali merasa minder dan sulit untuk bersosalisasi sehingga akan sulit mendapatkan pekerjaan dan berdampak pada taraf ekonomi. Adapun solusi yang dapat ditawarkan untuk penyelesaian mitra KPD Kusta Puskesmas meningkatkan ketrampilan anggota KPD Kusta dalam pembuatan kompos dan mol. Saat ini, pertanian organik kembali banyak diterapkan oleh petani dan merupakan upaya untuk memperbaiki kondisi tanah. Penambahan bahan organik ke dalam tanah diharapkan dapat meningkatkan produksi pertanian karena terjadinya keseimbangan dan ketersediaan hara akibat interaksi antara tanah, bahan organik dengan organisme tanah.

Larutan mol merupakan larutan berisi mikroorganime yang telah mengalami proses fermentasi dapat digunakan sebagai dekomposer dan pupuk cair untuk meningkatkan kesuburan tanah dan sumber unsur hara bagi pertumbuhan tanaman. Mikroorganisme merupakan makhluk hidup yang sangat kecil, mikroorganisme digolongkan ke dalam golongan protista yang terdiri dari bakteri, fungi, protozoa, dan algae ${ }^{1}$. Mol adalah hasil larutan fermentasi yang berbahan dasar dari sumber daya yang tersedia, mengandung unsur hara makro dan mikro mengandung mikroorganisme berpotensi sebagai perombak bahan organik, perangsang pertumbuhan dan agen pengendali hama dan 7 penyakit tanaman sehingga baik digunakan sebagai dekomposer, pupuk hayati, dan pestisida organik ${ }^{2}$.

Dengan tingkat kesadaran petani yang semakin tinggi akan perlunya kembali pada pertanian organik, maka salah satu peluang usaha yang bisa dikembangkan untuk membantu anggota KPD Kusta dari bidang pertanian adalah usaha dibidang pembuatan kompos dan mol karena tingginya tingkat permintaan pasar. Kabupaten Ponorogo secara umum kemudian khususnya kecamatan Slahung merupakan daerah dengan potensi pertanian yang sangat besar.

${ }_{1}^{1}$ Muljono Judoamidjojo, Abdul Aziz Darwis, and Endang Gumbira Sai'd, Teknologi Fermentasi (Rajawali Pers, 1992).

2 Mubiar Purwasasmita and Kabelan Kunia, "Mikroorganisme Lokal Sebagai Pemicu Siklus Kehidupan Dalam Bioreaktor Tanaman," in Seminar Nasional Teknik Kimia Indonesia, 2009, 19-20. 
Untuk membekali para anggota KPD Kusta tersebut agar lebih mandiri dari segi perekonomian, maka dilakukan kegiatan pelatihan pembuatan kompos dan mol ini. Teknik pembuatan kompos dan mol yang diajarkan pada pelatihan ini sangat mudah untuk dipraktekkan oleh anggota KPD karena pada prinsipnya, kompos dan mol dibuat dari bahan sederhana yang mudah ditemukan dipasaran. Tujuan dari pelatihan ini adalah setelah angggota KPD terampil membat kompos dan mol secara mandiri sehingga akan meningkatkan perekonomian keluarga anggota KPD kusta.

\section{Metode}

Kelompok KPD Kusta Sumber Waras Puskesmas Kecamatan Slahung beranggotakan 43 orang. Adapun anggota yang aktif dalam kegiatan pengabdian masyarakat ini berkisar 11-15 orang, dengan harapan nantinya dapat menyampaikan hasil kegiatan kepada para anggota lainnya. Rangkaian kegiatan dilaksanakan di aula Puskesmas Kecamatan Slahung. Tahapan dalam kegiatan pengabdian di KPD Kusta ini dibagi menjadi dua tahapan, yaitu tahapan persiapan dan tahapan pelaksanaan.

Tahapan persiapan meliputi kegiatan sosialisasi dan persiapan alat dan bahan untuk praktek. Kegiatan sosialisasi dilakukan untuk memberikan pemahaman kepada mitra tentang alur kegiatan yang akan dijalankan pada kegiatan pengabdian ini agar mitra bisa mengikuti rangkaian kegiatan dengan baik dan juga untuk meningkatkan partisipasi mitra. Diharapkan dengan sosialisasi, mitra akan tertarik dengan program pengabdian masyarakat ini dan akan hadir pada setiap rangkaian kegiatannya ${ }^{3}$. Tahapan persiapan berikutnya adalah tahapan penyiapan alat dan bahan untuk pembuatan mol. Setelah tahapan persiapan, tahapan berikutnya adalah tahapan pelaksanaan.

Tahapan pelaksaan meliputi kegiatan pemberian materi pembuatan kompos dan mol yang dilakukan dengan metode ceramah. Tahapan kegiatan ceramah dilaksanakan untuk menyampaikan konsep tentang kompos dan mol serta tahapan dalam pembuatan kompos dan mol. Selain itu dilakukan tahapan tanya jawab atau diskusi, sehingga apabila peserta pelatihan tidak jelas dengan materi yang disampaikan oleh narasumber dapat memberikan pertanyaan secara langsung pada sesi tanya jawab. Penggunaan metode ceramah dikombinasikan dengan memanfaatkan laptop dan

3 Amang Fathurrohman and Moh Awaludin Adam, "Persepsi Peternak Sapi Dalam Pemanfaatan Kotoran Sapi Menjadi Bi-Ogas Di Desa Sekarmojo Purwosari Pasuruan," Jurnal Ilmu-Ilmu Peternakan 25, no. 2 (2015): 36-42.

Volume 2, Number 1, Mei 2018|3

Penguatan Capacity Building pada Kelompok Perawatan Diri (KPD) Kusta Sumber Waras melalui Kegiatan Pemanfaatan Kompos dan Mikroorganisme Lokal (MOL) di Puskesmas Kecamatan Slahung Kabupaten Ponorogo 
LCD sehingga materi powerpoint yang dilengkapi dengan gambar-gambar bisa dengan mudah dipahami peserta karena materi pelatihan relatif banyak sedangkan waktu pelatihan yang terbatas. Tahapan pelaksanaan berikutnya adalah tahapan praktek pembuatan mol. Diharapkan dengan praktek secara langsung, mitra bisa secara mandiri melaksanakan kegiatan pembuatan mol.

\section{Hasil dan Diskusi}

Berdasarkan hasil survei awal, diketahui bahwa anggota KPD Kusta Sumber Waras berusia berkisar 45-60 tahun Pada rentang usia tersebut dapat dikatakan penderita telah berusia lanjut. Selain itu dapat diketahu bahwa sebagian besar keluarga penderita kusta adalah dari golongan ekonomi lemah. Padahal penyakit kusta jika tidak memperoleh pengobatan dapat menimbulkan cacat. Hal tersebut dapat menjadi halangan bagi penderita kusta dalam kehidupan bermasyarakat, termasuk untuk memenuhi kebutuhan sosial ekonomi. Disamping itu, masalah sosial lain yang dihadapi penderita kusata adalah dikucilkan oleh masyarakat. Dampaknya penderita maupun keluarga mengalami kesulitan untuk memperoleh pekerjaan. Sebagian besar penderita merupakan lansia yang sangat membutuhkan dukungan perekonomian dari keluarga. Seringkali justru para penderita diasingkan oleh keluarga. Hal tersebut menunjukkan bahwa diperlukan pendekatan baik penderita dan keluarganya, agar mampu mandiri secara terutama secara ekonomi dan berperan aktif dalam kegiatan sosial masyarakat.

Melihat permasalahan tersebut, kegiatan pengabdian masyarakat diarahkan untuk menyelesaikan permasalahan mitra tersebut. Deskripsi permasalahan, solusi yang ditawarkan dan indikator keberhasilan kegiatan pengabdian masyarakat disajikan pada tabel 1.

Tabe1 1. Permasalahan, solusi yang ditawarkan dan indikator keberbasilan kegiatan pengabdian masyarakat

\begin{tabular}{|c|c|c|c|}
\hline No. & $\begin{array}{c}\text { Deskripsi } \\
\text { Permasalahan }\end{array}$ & $\begin{array}{l}\text { Solusi yang } \\
\text { Ditawarkan }\end{array}$ & Indikator \\
\hline \multirow[t]{2}{*}{1.} & $\begin{array}{l}\text { Ekonomi penderita dan } \\
\text { keluarga KPD } \\
\text { merupakan golongan }\end{array}$ & $\begin{array}{l}\text { Peningkatan } \\
\text { ketrampilan mitra }\end{array}$ & $\begin{array}{ll}\text { Mitra } 1 & \text { memahami } \\
\text { teknis } & \text { pembuatan } \\
\text { kompos } & \end{array}$ \\
\hline & $\begin{array}{l}\text { kelas menengah ke } \\
\text { bawah }\end{array}$ & & $\begin{array}{l}\text { Mitra } 1 \text { terampil } \\
\text { membuat MOL }\end{array}$ \\
\hline 2. & $\begin{array}{l}\text { Masalah sosial yang } \\
\text { dihadapi dikucilkan } \\
\text { oleh masyarakat } \\
\text { bahkan keluarga sendiri }\end{array}$ & $\begin{array}{l}\text { Motivasi dan } \\
\text { pengembangan } \\
\text { kepribadian dengan } \\
\text { meningkatkan keahlian }\end{array}$ & $\begin{array}{ll}\text { Mitra } 1 \text { terampil } \\
\text { membuat } \\
\text { pupuk kompos dan } \\
\text { MOL yang dapat }\end{array}$ \\
\hline
\end{tabular}




\section{mitra}

dikerjakan bersama

lingkungan sekitar

Rangkaian kegiatan pengabdian masyarakat dapat dilihat pada tabel 2. Kegiatan pengabdian meliputi kegiatan pra pelaksanaan yaitu sosialisasi dan pesiapan alat dan bahan, kemudian dilaksanakan tahapan pelaksanaan kegiatan.

Kegiatan yang telah dilaksanakan disajikan pada tabel 2.

Tabe1 2. Rangkaian kegiatan dan Keterlibatan Mitra pengabdian masyarakat

\begin{tabular}{|lllll|}
\hline No & $\begin{array}{c}\text { Tanggal } \\
\text { Kegiatan }\end{array}$ & \multicolumn{1}{c}{ Rincian Kegiatan } & $\begin{array}{c}\text { Jumlah anggota mitra } \\
\text { yang terlibat }\end{array}$ & Keterlibatan Mitra \\
\hline 1. & 12 Januari 2017 & $\begin{array}{l}\text { Sosialisasi kegiatan } \\
\text { pengabdian kepada } \\
\text { mitra }\end{array}$ & 13 anggota mitra & $\begin{array}{l}\text { Aktif dalam kegiatan } \\
\text { sosialisasi }\end{array}$ \\
\hline 2. & Februari 2017 & $\begin{array}{l}\text { Persiapan alat dan } \\
\text { bahan }\end{array}$ & $\begin{array}{l}\text { Dilaksanakan oleh } \\
\text { pengabdi }\end{array}$ & - \\
\hline 3. 22 Maret 2017 & $\begin{array}{l}\text { Materi pembuatan } \\
\text { kompos }\end{array}$ & 13 anggota mitra & $\begin{array}{l}\text { Aktif menyimak } \\
\text { materi teknik } \\
\text { pembuatan kompos }\end{array}$ \\
\hline 4. 26 April 2017 & Materi pembuatan mol & 9 anggota mitra & $\begin{array}{l}\text { Aktif menyimak } \\
\text { materi pembuatan } \\
\text { mol dan juga praktek } \\
\text { pembuatan mol }\end{array}$ \\
\hline
\end{tabular}

Pemberian materi pembuatan kompos dilakukan di aula Puskesmas Kecamatan Slahung. Mitra sangat antusias menyimak materi yang diberikan dan aktif dalam kegiatan diskusi. Teknik pembuatan kompos yang diberikan merupakan teknik pembuatan kompos anaerob yang mudah dan sederhana sehingga nantinya akan bisa dilakukan secara mandiri oleh mitra. Potensi bahanbahan yang tersedia sebagai bahan pupuk organik di wilayah mitra yang bisa dimanfaatkan sebagai kompos diantaranya kotoran ternak (sapi, kambing) dan seresah tanaman habis panen yang bisa dijadikan kompos. Saat ini kompos banyak dibutuhkan petani, karena kompos menjadi banyak memberikan manfaat karena akan meningkatkan kandungan unsur hara makro dan mikro serta akan memperbaiki struktur tanah"

Murbandono menyatakan bahwa proses pengomposan memerlukan waktu yang cukup

${ }^{4}$ Murni Yuniwati, Frendy Iskarima, and Adiningsih Padulemba, “Optimasi Kondisi Proses Pembuatan Kompos Dari Sampah Organik Dengan Cara Fermentasi Menggunakan EM4," Jurnal Teknologi 5, no. 2 (2012): 172-181.

Volume 2, Number 1, Mei 2018| 5

Penguatan Capacity Building pada Kelompok Perawatan Diri (KPD) Kusta Sumber Waras melalui Kegiatan Pemanfaatan Kompos dan Mikroorganisme Lokal (MOL) di Puskesmas Kecamatan Slahung Kabupaten Ponorogo 
lama sekitar 3 sampai 4 bulan, hal ini disebabkan kompos terjadi secara alamiah sehingga mikroorganisme pengurai tersedia sedikit, oleh karena itu untuk mempercepat proses dekomposisi jerami sehingga lebih cepat menjadi kompos, saat ini telah banyak tersedia jenis dekomposer (bioaktivator) seperti Mikroorganisme Lokal (mol) ${ }^{5}$. Mol bisa dibuat dari bahan-bahan yang sederhana yang tersedia di lingkungan sekitar, selain itu, mol juga bisa dibuat dengan cara yang sederhana. Oleh karena itu, salah satu materi dalam kegiatan pengabdian masyarakat ini adalah pelatihan bagaimana membuat mol.

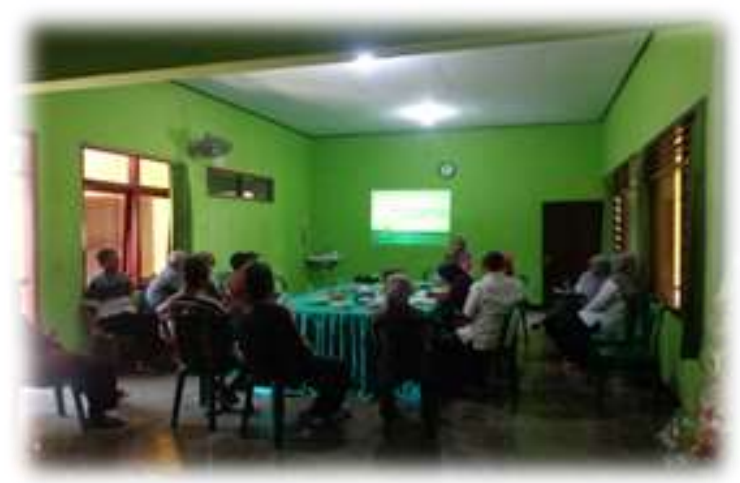

Gambar 1. Dokumentasi sosialisasi program pengabdian masyarakat kepada Mitra

Sebelum dilakukan pembuatan mol terlebih dahulu dilakukan pemberian materi tentang pembuatan mol agar mitra memahami cara pembuatan mol dan memudahkan kegiatan praktek. Bahan utama dalam mol yang dipraktekkan dalam pengabdian masyarakat kali ini terdiri dari 3 komponen yaitu: (1) karbohidrat, dalam hal ini bahan yang digunakan adalah nasi basi; (2) glukosa, sumber glukosa dalam pembuatan mol kali ini adalah gula dan tetes tebu; (3) bakteri, pada mol yang dibuat oleh mitra, sumber bakteri berasal dari ikan busuk. Pembuatan mol, dimulai dengan penyiapan cucian beras, air kelapa dan gula, kemudian dimasukkan ke dalam ember dan diaduk hingga rata. Kemudian, nasi busuk, ikan busuk, serta bonggol pisang yang telah dipotong kecilkecil dimasukkan dan diaduk rata. Setelah semua selesai, disiapkan potongan bambu yang berdiameter $\pm 10-15 \mathrm{~cm}$. Nasi basi yang akan diuraikan oieh bakteri mengandung unsur mikro dan makro serta mengandung bakteri yang berpotensi sebagai perombak bahan organik, perangsang tumbuhan serta mampu mengendalikan hama dan penyakit tanaman, sehingga mol dapat digunakan baik sebagai pendekomposer pupuk hayati dan sebagai pestisida organik terutama ${ }^{6}$. Air

\footnotetext{
5 Leonardus Murbandono Hadisumitro, “Membuat Kompos,” Penebar Swadaya. Jakarta (2002).

6 Purwasasmita and Kunia, "Mikroorganisme Lokal Sebagai Pemicu Siklus Kehidupan Dalam Bioreaktor Tanaman."
}

Volume 2, Number 1, Mei 2018 | 6

Penguatan Capacity Building pada Kelompok Perawatan Diri (KPD) Kusta Sumber Waras melalui Kegiatan Pemanfaatan Kompos dan Mikroorganisme Lokal (MOL) di Puskesmas Kecamatan Slahung Kabupaten Ponorogo 


\section{ENGAGEMENT}

Gurnal Pengabdian Kepada Masyarakat

ISSN: 2579-8375 (Print)

ISSN: 2579-8391 (Online)

kelapa yang ditambahkan sebagai bahan mol berfungsi untuk media bagi pertumbuhan mikroorganisme selama proses fermentasi berlangsung. Air kelapa diketahui mengandung karbohidrat, protein dan berbagai macam mineral ${ }^{7}$. Bahan lain yang digunakan untuk mol dalah bonggol pisang sebagai bahan mol, yang akan membantu meningkatkan kandungan mikroorganisme dalam molyaitu Bacillus sp., Aeromonas sp., Aspergillus nigger, Azospirillium, Azotobacter. dan mikroba selulolitik. Mikroba tersebut akan membantu menguraikan bahan organik sehingga mol akan membantu mempercepat pengomposan ${ }^{8}$. Bahan lain yang dapat digunakan dalam pembuatan mol antara lain urin sapi, daun gamal, buah-buahan busuk, sampah rumah tangga serta rumput gajah ${ }^{9}$.
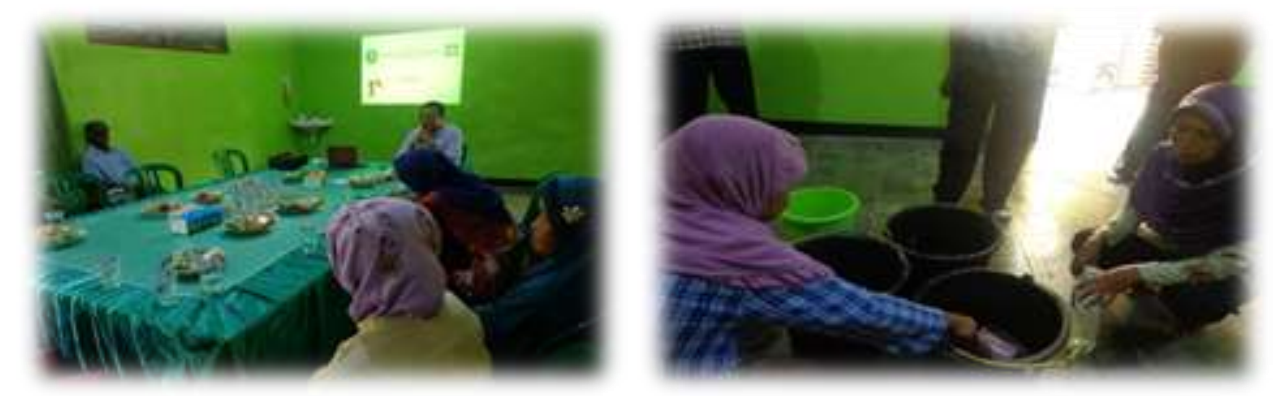

Gambar 2. Dokumentasi pemberian materi dan praktikum pembuatan kompos

Bahan-bahan mol tersebut kemudian dimasukkan ke dalam bambu, kemudian potongan bambu ditutup rapat menggunakan pohon pisang yang sudah disesuaikan ukurannya dengan lubang bambu lalu dibungkus plastik dan diikat dengan karet. Bambu tersebut kemudian ditimbun dalam tanah agar suhu lingkungan stabil. Tujuan dari penggunaan bambu adalah mencegah terkena cahaya matahari secara langsung pada saat proses fermentasi. Praktek pembuatan mol yang dibeerikan kepada mitra sangat mudah diaplikasikan karena caranya sederhana dan bahannya mudah didapatkan. Mitra antusias dalam melaksanakan kegiatan pembuatan mol. Setelah 1 bulan, mol siap digunakan.

Mol memiliki banyak keunggulan, diantarnya harganya murah dan dapat memanfaatkan bahan-bahan di alam sekitar yang tidak terpakai seperti bonggol pisang, air kelapa, buah dan (2002).

${ }^{7}$ Moch Agus Kresno Budiyanto, "Mikrobiologi Terapan," Universitas Muhammadiyah, Malang 159

${ }^{8} \mathrm{Ni}$ Komang Budiyani and Ni Komang Budiyani, "Analisis Kualitas Larutan Mikroorganisme Lokal (MOL) Bonggol Pisang" (Universitas Udayana, 2015).

${ }^{9}$ N W S Sutari, “Uji Berbagai Jenis Pupuk Cair Biourine Terhadap Pertumbuhan Dan Hasil Tanaman Sawi Hijau (Brassica Juncea L.)," Agritrop: Jurnal Ilmu-Ilmu Pertanian (Journal On Agricultural Sciences) edisi 29 (2010).

Volume 2, Number 1, Mei 2018 | 7

Penguatan Capacity Building pada Kelompok Perawatan Diri (KPD) Kusta Sumber Waras melalui Kegiatan Pemanfaatan Kompos dan Mikroorganisme Lokal (MOL) di Puskesmas Kecamatan Slahung Kabupaten Ponorogo 
sayuran busuk bahkan sisa cucian beras dan sisa-sisa makanan. Mol memiliki kelebihan karena: (a) efektif mengurangi volume timbunan sampah dan membantu mempercepat proses degradasi sampah menjadi humus, (c) efektif menekan timbulnya masalah sosial/mengganggu kenyamanan lingkungan, (d) dari aspek lingkungan, kompos efektif memperbaiki sifat fisik dan biologis tanah, dapat digunakan kapan saja, aman dan tidak merusak lingkungan mol berbahan dasar nasi basi diketahui menghasilkan bakteri pengurai yang dapat digunakan sebagai aktivator pada pembuatan kompos organik. Pembuatan mol ini juga sangat mudah dan praktis sehingga berpotensi untuk dikembangkan pembuatan aktivator pengomposan secara alami dan mandiri berupa mol.

\section{Simpulan}

Dari kegiatan pengabdian masyarakat, dapat disimpulkan bahwa melalui pengabdian ini maka mitra telah memahami materi mampu membuat mol dan kompos. Selain itu, kegiatan pengabdian masyarakat ini juga telah mampu mengatasi permasalahan mitra, diantaranya memberikan alternatif ketrampilan di bidang pertanian sebagai salah satu upaya peningkatan ekonomi para penderita kusta. Melalui kegiatan ini juga mampu memberikan motivasi pengembangan kepribadian dan menjalin jejaring sehingga permasalahan terkait dengan pengucilan oleh masyarakat dan keluarga dapat diminimalisir.

\section{Daftar Referensi}

Budiyani, Ni Komang, and Ni Komang Budiyani. "Analisis Kualitas Larutan Mikroorganisme Lokal (MOL) Bonggol Pisang.” Universitas Udayana, 2015.

Budiyanto, Moch Agus Kresno. "Mikrobiologi Terapan.” Universitas Muhammadiyah, Malang 159 (2002).

Fathurrohman, Amang, and Moh Awaludin Adam. "Persepsi Peternak Sapi Dalam Pemanfaatan Kotoran Sapi Menjadi Bi-Ogas Di Desa Sekarmojo Purwosari Pasuruan.” Jurnal Ilmu-Ilmu Peternakan 25, no. 2 (2015): 36-42.

Hadisumitro, Leonardus Murbandono. "Membuat Kompos.” Penebar Swadaya. Jakarta (2002).

Judoamidjojo, Muljono, Abdul Aziz Darwis, and Endang Gumbira Sai'd. Teknologi Fermentasi. Rajawali Pers, 1992.

Purwasasmita, Mubiar, and Kabelan Kunia. "Mikroorganisme Lokal Sebagai Pemicu Siklus Kehidupan Dalam Bioreaktor Tanaman." In Seminar Nasional Teknik Kimia Indonesia, 19-20, 2009.

Sutari, N W S. "Uji Berbagai Jenis Pupuk Cair Biourine Terhadap Pertumbuhan Dan Hasil Tanaman Sawi Hijau (Brassica Juncea L.).” Agritrop: Jurnal Ilmu-Ilmu Pertanian (Journal On Agricultural Sciences) edisi 29 (2010).

Yuniwati, Murni, Frendy Iskarima, and Adiningsih Padulemba. "Optimasi Kondisi Proses Pembuatan Kompos Dari Sampah Organik Dengan Cara Fermentasi Menggunakan EM4." Jurnal Teknologi 5, no. 2 (2012): 172-181. 